\title{
A High Molar Extinction Coefficient Ru(II) Complex Functionalized with cis-Dithiocyanato-bis-(9-anthracenyl-10- (2-methyl-2-butenoic acid)-1,10-phenanthroline): Potential Sensitizer for Stable Dye-Sensitized Solar Cells
}

\author{
Adewale O. Adeloye and Peter A. Ajibade \\ Department of Chemistry, Faculty of Science and Agriculture, University of Fort Hare, Private Bag X1314, Alice 5700, South Africa \\ Correspondence should be addressed to Peter A. Ajibade; pajibade@ufh.ac.za
}

Received 12 November 2013; Revised 5 February 2014; Accepted 5 February 2014; Published 28 April 2014

Academic Editor: Mengqing Xu

Copyright (C) 2014 A. O. Adeloye and P. A. Ajibade. This is an open access article distributed under the Creative Commons Attribution License, which permits unrestricted use, distribution, and reproduction in any medium, provided the original work is properly cited.

\begin{abstract}
New heteroleptic ruthenium(II) complex was formulated as $\left[\mathrm{Ru}\left(\mathrm{L}_{1}\right)_{2}(\mathrm{NCS})_{2}\right]$, where $\mathrm{L}_{1}=9$-anthracenyl-10-(2-methyl-2-butenoic acid)-1,10-phenanthroline was synthesized and its photophysical properties were studied and compared to previously reported analogue complex containing no anthracene moiety $\left[\mathrm{Ru}\left(\mathrm{L}_{2}\right)_{2}(\mathrm{NCS})_{2}\right], \mathrm{L}_{2}=(2$-methyl-2-butenoic acid)-1,10-phenanthroline. The two complexes though exhibit very strong molar extinction coefficient values; however, $\left[\mathrm{Ru}\left(\mathrm{L}_{1}\right)_{2}(\mathrm{NCS})_{2}\right]$ shows better characteristic broad and intense metal-to-ligand charge transfer (MLCT) absorption band and higher molar absorptivity coefficient at $\left(\lambda_{\max }=\right.$ $\left.522 \mathrm{~nm}, \varepsilon=6.60 \times 10^{4} \mathrm{M}^{-1} \mathrm{~cm}^{-1}\right)$ than that of $\left[\mathrm{Ru}\left(\mathrm{L}_{2}\right)_{2}(\mathrm{NCS})_{2}\right]$ complex, $\left(\lambda_{\max }=446 \mathrm{~nm}, \varepsilon=4.82 \times 10^{4} \mathrm{M}^{-1} \mathrm{~cm}^{-1}\right)$. At room temperature, long wavelength emissions with strong intensity ratio centered at $660 \mathrm{~nm}$ were recorded for $\left[\mathrm{Ru}\left(\mathrm{L}_{1}\right)_{2}(\mathrm{NCS})_{2}\right]$ complex with a bathochromic shift $\left(\lambda_{\mathrm{em}}=700 \mathrm{~nm}\right)$ for $\left[\mathrm{Ru}\left(\mathrm{L}_{2}\right)_{2}(\mathrm{NCS})_{2}\right]$ complex. It was shown that the luminescence wavelength characteristic of the complexes may be a function relating to the increasing length of $\pi$-conjugation and/or molecular weight. A preliminary cyclic voltammetry of $\left[\mathrm{Ru}\left(\mathrm{L}_{1}\right)_{2}(\mathrm{NCS})_{2}\right]$ complex also exhibits good electroredox activity with oxidation potential of about $1.04 \mathrm{~V}$, significantly better than other $\mathrm{Ru}(\mathrm{II})$ polypyridine complexes containing bidentate ligands.
\end{abstract}

\section{Introduction}

The search for efficient solar energy conversion devices is an important area of research [1-7]. Among all major constituents vital to dye-sensitized solar cells (DSCs), photosensitizers are responsible for light harvesting, while suitable photoanodes, redox couples, and counter electrodes are utilized to achieve efficient charge separation, collection, and transportation. The major challenge of this emergent technology is to integrate each of the components into a highly efficient, single photonic device [8-15]. Recently, an order of magnitude increase in solar energy conversion efficiencies at dye-sensitized photoelectrochemical cells has been realized [16-22]. This breakthrough was accomplished by attaching ruthenium polypyridyl complexes to high surface area titanium dioxide, $\mathrm{TiO}_{2}$, electrodes when operating as photoanodes in a photoelectrochemical cells; these materials efficiently convert visible light to electricity $[23,24]$. Research on artificial photosynthetic devices based on this technology provides an opportunity to directly convert light energy into electricity on a molecular level. Since it is expected that most inorganic charge transfer complexes possess unique ground and excited state properties, it is not surprising to find that solar energy conversion efficiencies are dependent on the nature of the molecular dye sensitizer. Ruthenium polypyridine complexes are widely used as photosensitizers in covalently linked multicomponent systems. Their photophysical properties make them ideal candidates as building blocks for the design of supramolecular species performing complex light induced functions [25-28]. These complexes offer desirable redox properties, excited-state reactivity, luminescent emission, and excited-state lifetimes [29-36]. 
Previous study has shown that metal-to-ligand charge transfer (MLCT) sensitizers with positive metal-based oxidation potentials have the disadvantage of exhibiting high energy absorption bands which only harvest a fraction of visible light $[25,26]$. For complexes of the type cis$\mathrm{Ru}(\mathrm{LL})_{2} \mathrm{X}_{2}$ (where LL is bidentate polypyridine ligands and $\mathrm{X}$ is ancillary ligands) intense MLCT absorption bands are often observed from 400 to $600 \mathrm{~nm}$ with negligible absorption at longer wavelengths [22]. The MLCT absorption can be extended to lower energy by appropriate substituent changes in the chromophoric ligands or by decreasing the $\mathrm{d} \pi-\pi^{*}$ backbonding donation of the nonchromophoric ligands. The effect of these changes on the photophysical properties of metal polypyridine complexes has been the subject of several investigations which have given fundamental insight into the factors, which govern radiative and nonradiative decay processes of excited states $[25,26]$.

In an attempt to extend the spectral sensitivity of dye molecules towards the red, we have designed a new cis- $\mathrm{Ru}(\mathrm{LL})_{2}-(\mathrm{X})_{2}$ polypyridine complex based on the ligand 5-(9-anthracenyl-10-(trans-2-methyl-2-butenoic acid)1,10-phenanthroline) with extended $\pi^{*}$ accepting orbitals at lower energy and the photophysical properties compared to the previously reported heteroleptic $\mathrm{Ru}(\mathrm{II})$ complex of 5(trans-2-methyl-2-butenoic acid)-1,10-phenanthroline ligand [37]. The photoelectrochemical characteristics exhibited by the complex are rationalized in terms of spectroscopical and photophysical properties measured in fluid solution. As envisaged, enhanced spectral response was found for complex containing anthracenyl functionality as compared to that without anthracene. However, of particular relevance in the context of this report in relation to our previous studies and reports on the increasing number of anthracene functionality in a particular ruthenium polypyridyl complex in which molar extinction coefficient values are reduced due to molecular aggregation [38-40]. On the basis of this, we set out to investigate and discuss the photophysical and electrochemical properties of a new-type monoanthracenyl functionalized phenanthroline heteroleptic ruthenium(II) complex in relation to its potential use as a photosensitizer for application in the dye-sensitized solar cells (DSSCs) and other optoelectronic devices.

\section{Results and Discussion}

2.1. Chemistry. Scheme 1 (i-iii) shows the stepwise synthetic pathways for $\mathrm{L}_{1}$ and $\mathrm{L}_{2}$ and outlines the chemistry of the present study. 9,10-Dibromoanthracene, 2-methyl-2butenoic acid, and 1,10-phenanthroline are the starting materials for 1 and 2. 9-Bromo-10-(2-methyl-2-butenoic acid)anthracene (1) was obtained when 9,10-dibromoanthracene and 2-methyl-2-butenoic acid were refluxed in a benzene/dichloromethane mixture under basic condition using triethylamine, potassium hydroxide, and palladium carbide. Product 2 was obtained by the initial introduction of required bromine functions on 1,10-phenanthroline under an environmentally benign condition as reported by Vyas and coworkers [41]. $\mathrm{L}_{1}$ and $\mathrm{L}_{2}$ were synthesized following slight modifications of established procedures reported in the literature [40]. The synthesis of $\mathrm{L}_{1}$ essentially follows two major reaction steps: the initial synthesis of a 2-methyl-2butenoic acid functionalized anthracenyl group followed by a palladium cross-catalyzed reaction of two halide compounds. This reaction was aided by the use of an equivalent volume ratio of dichloromethane-benzene as solvent to overcome the poor solubility of anthracenyl derivatives in common organic solvents such as methanol and chloroform. It was found that this reaction could be reversed by first reaction of the halogenated polypyridine with 9,10-dibromoanthracene and a subsequent dehydrohalogenation reaction with 2-methylbutenoic acid. $\mathrm{L}_{2}$ was obtained by one-step nucleophilic aromatic substitution reaction of the bromide group of product 2 with 2-methyl-2-butenoic acid. The synthesis of the metal precursor $\left[\mathrm{RuCl}_{2}(\mathrm{dmso})_{4}\right][42]$ and the complexes $\left[\mathrm{Ru}\left(\mathrm{L}_{1}\right)_{2}(\mathrm{NCS})_{2}\right]$ and $\left[\mathrm{Ru}\left(\mathrm{L}_{2}\right)_{2}(\mathrm{NCS})_{2}\right]$ followed the general synthetic route shown in Scheme 1 (iv and v). Sequential substitution of the DMSO coordinating ligand from the metal precursor led to formation of intermediate complex $\left[\mathrm{Ru}\left(\mathrm{L}_{x}\right)_{2} \mathrm{Cl}_{2}\right]\left(\mathrm{L}_{x}=\mathrm{L}_{1}\right.$ or $\left.\mathrm{L}_{2}\right)$ which was not isolated. Final reaction was carried out with chloride exchange with thiocyanate group [43].

2.2. Infrared Spectra. The FT-IR spectra of the starting materials, the ligands, and the complex showed certain characteristic absorption bands that were compared and assigned on careful comparison. Due to structural similarities between the ligand and the complex, a strong band in the region $3479-3055 \mathrm{~cm}^{-1}$ was found. This gave indication of the presence of an $\mathrm{O}-\mathrm{H}$ group possibly from the carboxylic acid moiety. This band, however, shifted to higher frequency at $3551 \mathrm{~cm}^{-1}$ in the complex (Figure 1). The vibration frequency bands between 3479 and $3237 \mathrm{~cm}^{-1}$ may be due to presence of $\alpha$-, $\beta$-unsaturated carboxylic acid and/or aromatic $\mathrm{C}-\mathrm{H}$ stretching characteristics of the molecules. The band at $2928 \mathrm{~cm}^{-1}$ shows the presence of $\mathrm{C}-\mathrm{H}$ stretching of methyl groups. The complex shows a broad absorption frequency at $2104 \mathrm{~cm}^{-1}$ for stretch vibrational modes due to the N-coordinated $v(\mathrm{CN})$. This band is reduced in intensity compared to the band at $926 \mathrm{~cm}^{-1}$, due to $v(\mathrm{CS})$. The bands at $1971,1638 \mathrm{~cm}^{-1}, 1309$, and $1256 \mathrm{~cm}^{-1}$, were assigned to the $v(\mathrm{C}=\mathrm{O})$ and $v(\mathrm{C}-\mathrm{O})$ stretching of carboxylic acid groups, respectively. The singlet sharp band at $1617 \mathrm{~cm}^{-1}$ is assigned to the aromatic $\mathrm{C}-\mathrm{N}$ stretch vibration with the two bands at 1459 and $1438 \mathrm{~cm}^{-1}$ due to ring stretching modes of the ligands. A comparison of the infrared spectra of $\mathbf{L}_{1}$ and 9,10dibromoanthracene showed that a strong vibrational band in the former was conspicuously absent in the latter, confirming the loss of $\mathrm{C}-\mathrm{Br}$ bond and the formation of $\mathrm{C}-\mathrm{C}$ bond linkages of the anthracenyl group. Furthermore, the $\mathrm{C}-\mathrm{C}$ bond linkage between anthracene and phenanthroline was affirmed by the absorption frequency at $804 \mathrm{~cm}^{-1}$. Peaks in the region at 747 and $730 \mathrm{~cm}^{-1}$ demonstrate the existence of four adjacent hydrogen atoms common to $\mathrm{L}_{\mathbf{1}}$ and complex $\left[\mathrm{Ru}\left(\mathrm{L}_{1}\right)_{2}(\mathrm{NCS})_{2}\right]$. All vibrational peaks in the region are found to be relatively weak and broad in the complex, which may be ascribed to the loss of crystallinity and the broad 
(i)<smiles>C/C=C(\C)C(=O)O</smiles>

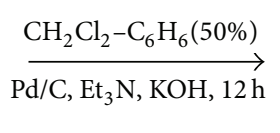<smiles>C/C(C(=O)O)=C(/C)c1c2ccccc2c(Br)c2ccccc12</smiles><smiles>C/C(C(=O)O)=C(/C)c1c2ccccc2c(Br)c2ccccc12</smiles>

(ii)

(1)<smiles>Brc1cc2cccnc2c2ncccc12</smiles>

$\mathrm{Pd} / \mathrm{C}, \mathrm{ET}_{3} \mathrm{~N}, \mathrm{KOH}, 12 \mathrm{~h}$

(iv)

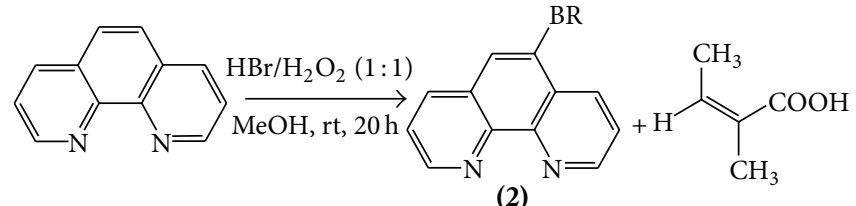

(2)

(1) Reflux, $100^{\circ} \mathrm{C}, 10 \mathrm{~min} \longrightarrow\left[\mathrm{RuCl}_{2}\left(\left(\mathrm{CH}_{3}\right)_{2} \mathrm{SO}\right)_{4}\right.$
$\left[\mathrm{RuCl}_{3}\left(\mathrm{H}_{2} \mathrm{O}\right)\right]+4\left(\mathrm{CH}_{3}\right)_{2} \mathrm{SO} \underset{(2) \text { Washed in acetone }}{\longrightarrow}$ Yellow powder
$\left(\mathrm{L}_{1}\right)$<smiles></smiles>

(iii)

(i) $\mathrm{MeOH}, \mathrm{Pd} / \mathrm{C}$

(ii) $\mathrm{KOH}, \mathrm{Et}_{3} \mathrm{~N}, 8$<smiles>C/C(C(=O)O)=C(/C)c1cc2cccnc2c2ncccc12</smiles>

$\left(\mathrm{L}_{2}\right)$

(v)

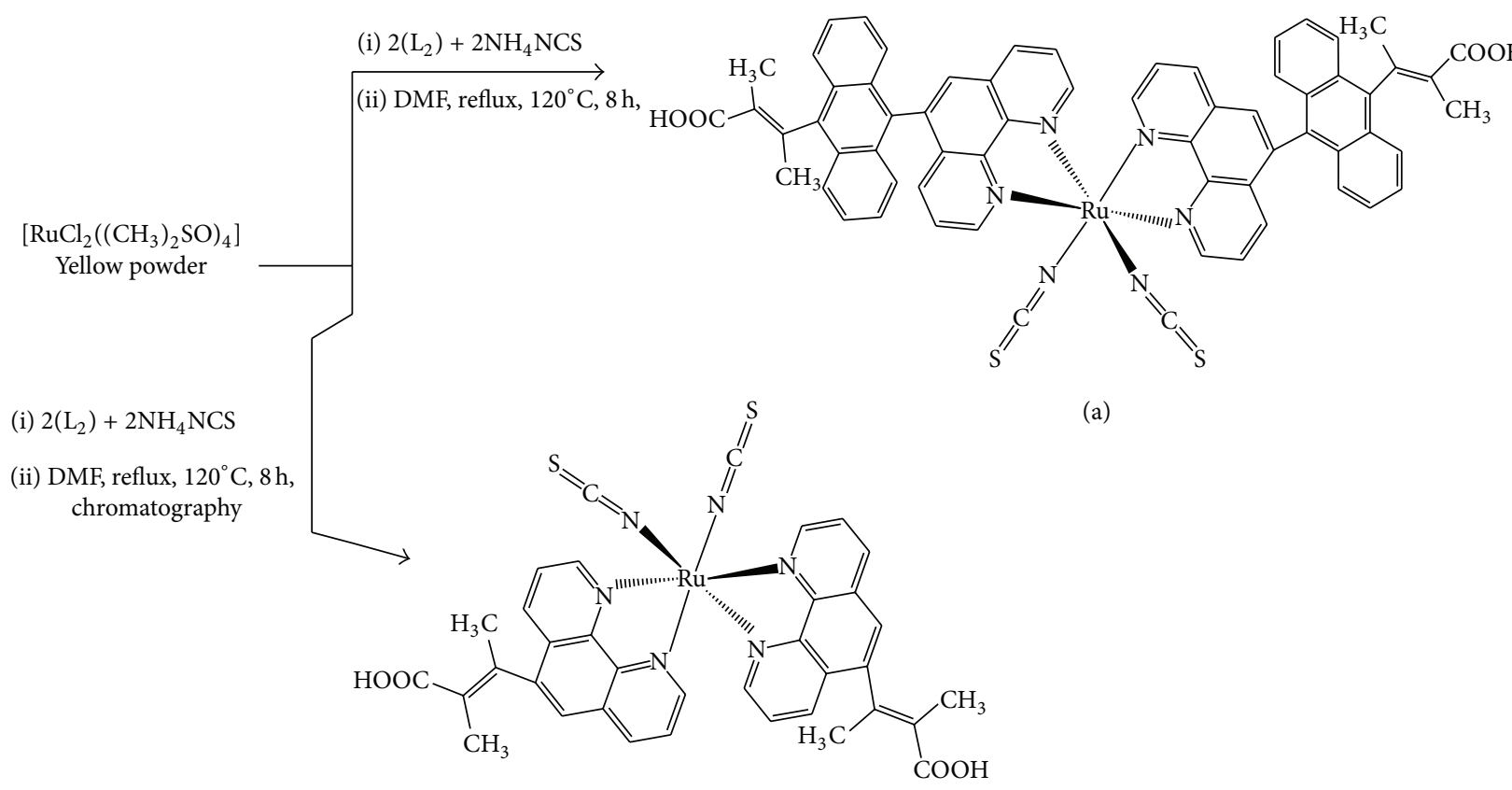

(b)

Scheme 1: Synthetic pathways for ligands $\mathrm{L}_{1}$ and $\mathrm{L}_{2}$ and complexes $\left[\mathrm{Ru}\left(\mathrm{L}_{1}\right)_{2}(\mathrm{NCS})_{2}\right]$ and $\left[\mathrm{Ru}\left(\mathrm{L}_{2}\right)_{2}(\mathrm{NCS})_{2}\right]$.

distribution of the anthracene chain length [36]. The weak absorption frequencies at 475 and $404 \mathrm{~cm}^{-1}$, respectively, show the coordination of nitrogen atoms of the ancillary ligands to ruthenium central metal atom [44].

2.3. NMR Spectroscopy. The ${ }^{1} \mathrm{H}-\mathrm{NMR}$ of $\mathbf{L}_{\mathbf{1}}$ due to molecular symmetry showed five major signals at the aromatic region at $\delta 9.18(\mathrm{~d}, J=3.2 \mathrm{~Hz}), 8.23(\mathrm{~d}, J=7.2 \mathrm{~Hz}), 7.77(\mathrm{~s}), 7.62(\mathrm{dd}$, $J=4.4,8.0 \mathrm{~Hz})$, and $6.97(\mathrm{~d}, J=7.2 \mathrm{~Hz})$; these peaks were assigned to the phenanthroline and anthracene protons. The two signals in the aliphatic region at $\delta 1.81\left(\mathrm{t}, \mathrm{CH}_{3}\right)$ and 1.23 $\left(\mathrm{t}, \mathrm{CH}_{3}\right)$ were unambiguously assigned to the trans-methyl protons of the carboxylic acid group (Figure 2 ). The ${ }^{13} \mathrm{C}$ spectrum peaks of the $\mathbf{L}_{\mathbf{1}}$ ligand (Figure 3 ) showed important diagnostic peaks depicting the presence of phenanthroline, anthracene, and the 2 -dimethyl substituted $\alpha$-, $\beta$-unsaturated carboxylic acid. At the aromatic region, a peak at $\delta 150.28$ was tentatively assigned to the $\mathrm{C}=\mathrm{O}$ of the acidic group 


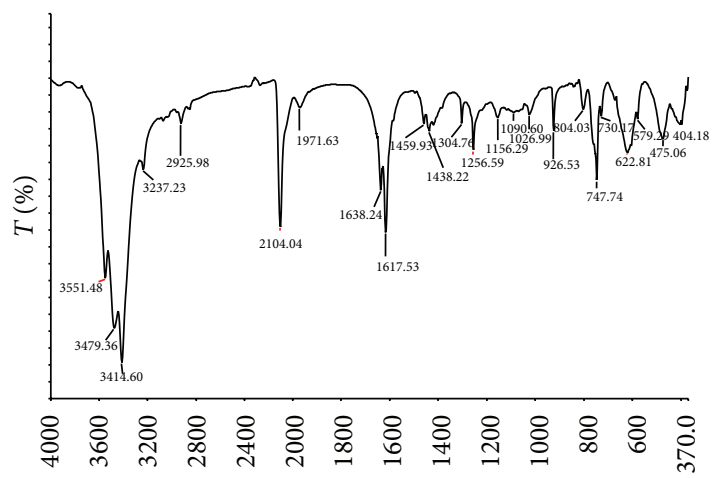

FIgURE 1: FT-IR spectrum of $\left[\mathrm{Ru}\left(\mathrm{L}_{1}\right)_{2}(\mathrm{NCS})_{2}\right]$ complex in $\mathrm{KBr}$.

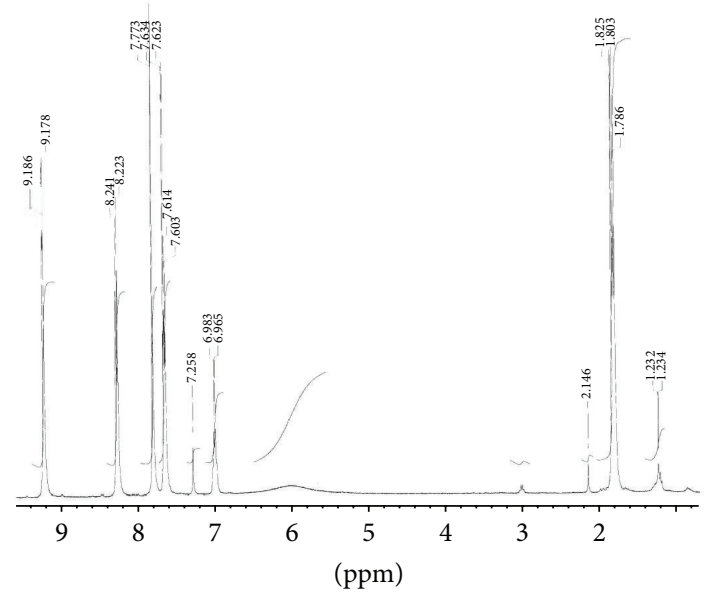

FIgURE 2: ${ }^{1} \mathrm{H}$ NMR spectrum of $\mathbf{L}_{\mathbf{1}}$ in $\mathrm{CDCl}_{3}$.

and/or the $\mathrm{C}=\mathrm{N}$ of the phenanthroline framework. Increase in the $\pi$-bond conjugation in molecules is known to cause upfield shifts for all types of carbonyl compounds due to strong electron density delocalization [45]. The reduced peak signals at $\delta 146.19,139.25$, and $128.61 \mathrm{ppm}$ were assigned to the quaternary carbon atoms. Three strong peaks at $\delta$ $135.98,126.50$, and $123.06 \mathrm{ppm}$ were assigned to the methine groups of the ligand. At the aliphatic region, the two methyl groups showed conspicuous peaks at $\delta 14.42$ and $11.74 \mathrm{ppm}$. Good ${ }^{1} \mathrm{H}$ and ${ }^{13} \mathrm{C}$-NMR spectra resolutions were difficult to obtain for the corresponding $\left[\mathrm{Ru}\left(\mathrm{L}_{1}\right)_{2}(\mathrm{NCS})_{2}\right]$ complex. However, in the aromatic region of the ${ }^{1} \mathrm{H}-\mathrm{NMR}$, it was observed that the two major symmetric signals assigned to the anthracene protons dominate the spectrum at $\delta 8.59$ (dd, $J$ $=4.8,7.2 \mathrm{~Hz})$ and $7.63(\mathrm{dd}, J=2.8,6.8 \mathrm{~Hz})$, the phenanthroline proton peak signals were found at a very much reduced intensity (Figure 4). The aliphatic region of the spectrum, however, gave interesting information with the presence of four downfield singlet peak signals at $\delta 2.95,2.88,2.17$, and $2.04 \mathrm{ppm}$ which were assigned to the methyl signals of the carboxylic acid groups. The reason for the splitting into four different singlet peaks is unclear at the moment, but it could be inferred that the two outer anchoring ligands in the complex possibly have different spatial orientation as

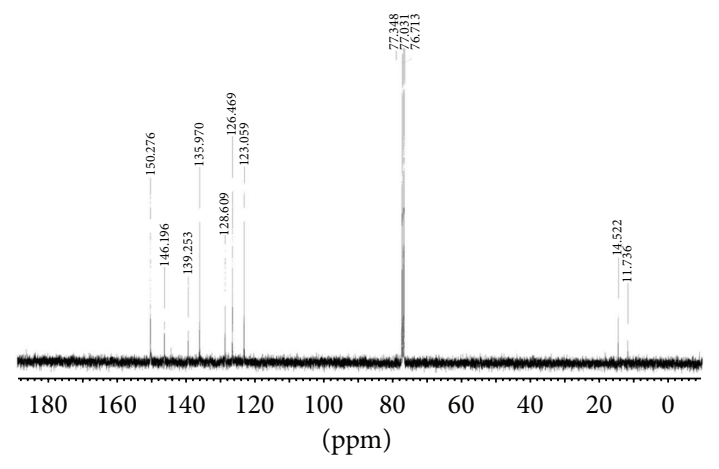

Figure 3: ${ }^{13} \mathrm{C}$ NMR spectrum of $\mathbf{L}_{\mathbf{1}}$ in $\mathrm{CDCl}_{3}$.

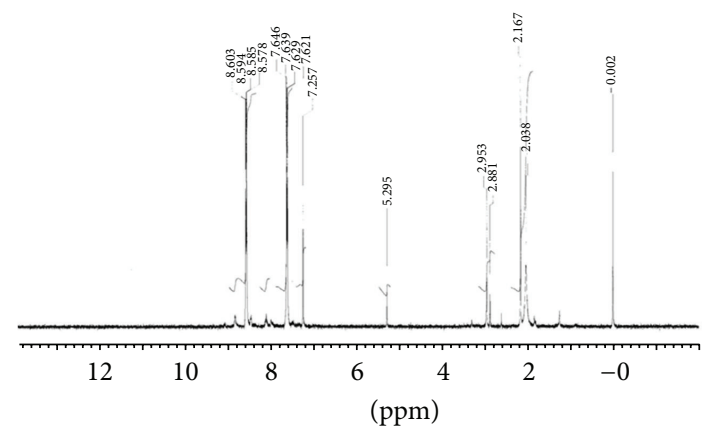

FIgURE $4:{ }^{1} \mathrm{H}$ NMR spectrum of $\left[\mathrm{Ru}\left(\mathrm{L}_{1}\right)_{2}(\mathrm{NCS})_{2}\right]$ complex.

opposed to the symmetry found in a single $\left(\mathrm{L}_{1}\right)$ ligand before complexation.

\subsection{Electronic Absorption and Emission Spectra}

2.4.1. Electronic Absorption Spectroscopy. The UV-Vis absorbance and emission spectra of complex $\left[\mathrm{Ru}\left(\mathrm{L}_{1}\right)_{2}(\mathrm{NCS})_{2}\right]$ were recorded at room temperature in aerated DMF solution and are shown in Figures 5, 6, and 7 , respectively. The complex exhibits a very broad and intense metal-to-ligand charge (MLCT) absorption band throughout the visible region of the spectrum $(430-700 \mathrm{~nm})$ characteristics of many other ruthenium(II) polypyridyl complexes which can be assigned to electronic transitions from the $\mathrm{Ru}^{\mathrm{II}}$ based $\mathrm{t}_{2} \mathrm{~g}$ orbital to the ligand based $\pi^{*}$ orbitals. The molar extinction coefficient of $\left[\mathrm{Ru}\left(\mathrm{L}_{1}\right)_{2}(\mathrm{NCS})_{2}\right]$ complex centered at its maximum $522 \mathrm{~nm}$ is $6.60 \times 10^{4} \mathrm{M}^{-1} \mathrm{~cm}^{-1}$, about $73 \%$ larger than that of $\left[\mathrm{Ru}\left(\mathrm{L}_{2}\right)_{2}(\mathrm{NCS})_{2}\right](4.82 \times$ $10^{4} \mathrm{M}^{-1} \mathrm{~cm}^{-1}$ ) with a blue shift at $446 \mathrm{~nm}$. The anthracenyl nature of the complex exhibits multiple distinct vibronic peaks for the intraligand $\left(\pi \rightarrow \pi^{*}\right)$ charge transfer transitions characteristics of anthracene derivatives at $348,365,383$, and $405 \mathrm{~nm}$. These bands enhance the oscillator strength in the blue and green portions of the spectrum relative to $\left[\mathrm{Ru}\left(\mathrm{L}_{2}\right)_{2}(\mathrm{NCS})_{2}\right]$ complex. These features have also been found as a means of improving light absorption cross sections at higher energy in similar complexes [46]. In addition, the higher absorption coefficient of the $\left[\mathrm{Ru}\left(\mathrm{L}_{1}\right)_{2}(\mathrm{NCS})_{2}\right]$ 


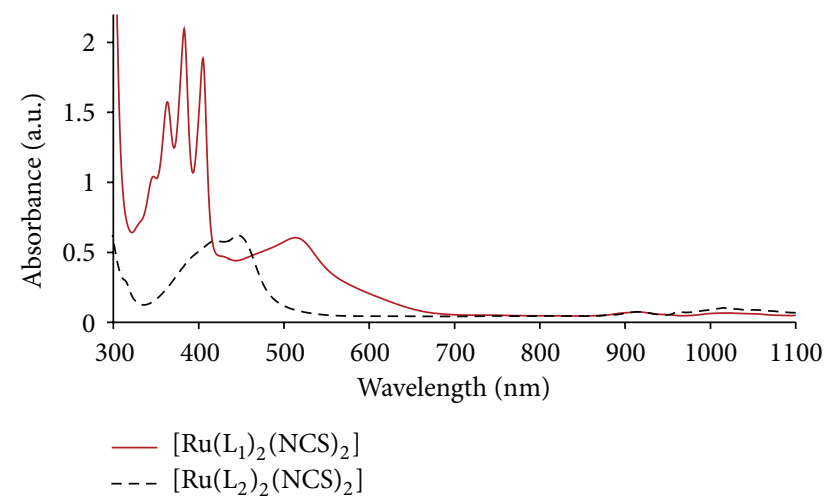

FIgURE 5: Comparison of the UV-V is absorption spectrum of $\left[\mathrm{Ru}\left(\mathrm{L}_{1}\right)_{2}(\mathrm{NCS})_{2}\right]$ (solid line) with $\left[\mathrm{Ru}\left(\mathrm{L}_{2}\right)_{2}(\mathrm{NCS})_{2}\right]$ (dash line) at a concentration of $1 \times 10^{-3} \mathrm{M}^{-1}$ in DMF solution showing effect of extended $\pi$-conjugation using anthracene.

complex, consequently, allows a thinner nanocrystalline $\mathrm{TiO}_{2}$ film to avoid the decrease of the mechanical strength. A thinner film also facilitates the electrolyte diffusion and reduces the recombination possibility of the light-induced charges during transportation [47]. The molar extinction coefficients of the two complexes descend steadily towards longer wavelengths. Noticeably, the complexes show a common weak shoulder in the near infrared region at $918 \mathrm{~nm}\left(\varepsilon=5734 \mathrm{M}^{-1} \mathrm{~cm}^{-1}\right)$ and general broad bands in the region of $965-1022 \mathrm{~nm}$ (Figure 6); these absorption bands are attributed to the ${ }^{3}$ MLCT triplet state excitation of the ruthenium(II) polypyridine complexes [39, 48]. The intense absorption band in the UV region around 280-300 nm (not shown) was assigned to the intraligand $\pi \rightarrow \pi^{*}$ transitions of $\mathrm{L}_{1}$ and $\mathrm{L}_{2}$ ligands. The lower-energy absorption in the two complexes may have been enhanced due to the presence of the electron withdrawing nature of the carboxylic groups which lowers the energy of the $\pi^{*}$ orbital of the phenanthroline ligands and a further stability of the complexes provided by the trans nature of the methyl groups [49].

2.4.2. Emission Study. The emission spectra of $\left[\mathrm{Ru}\left(\mathrm{L}_{1}\right)_{2}(\mathrm{NCS})_{2}\right]$ and $\left[\mathrm{Ru}\left(\mathrm{L}_{2}\right)_{2}(\mathrm{NCS})_{2}\right]$ are displayed in Figure 7. Upon excitation into the ${ }^{1} \mathrm{LC}$ and ${ }^{1} \mathrm{MLCT}$ bands $(470 \mathrm{~nm})$, both complexes display appreciable luminescence at room temperature. An emission wavelength maximum centered at $660 \mathrm{~nm}$ was recorded for $\left[\mathrm{Ru}\left(\mathrm{L}_{1}\right)_{2}(\mathrm{NCS})_{2}\right]$. It is interesting to note the red shift in emission wavelength maximum centered at $700 \mathrm{~nm}$ for $\left[\mathrm{Ru}\left(\mathrm{L}_{2}\right)_{2}(\mathrm{NCS})_{2}\right]$. As observed in the absorption spectra, the emission spectra show no shoulders, indicating probably the existence of only one emitting state and nondistortion of molecular structures in the two complexes. However, overall emission wavelengths show an inverse relationship with increase in absorption wavelength maxima. This may be explained in terms of the energy gap between the ground and the lowest excited states which monotonically increases as the extent of charge transfer of the electronic ground state decreases. The results

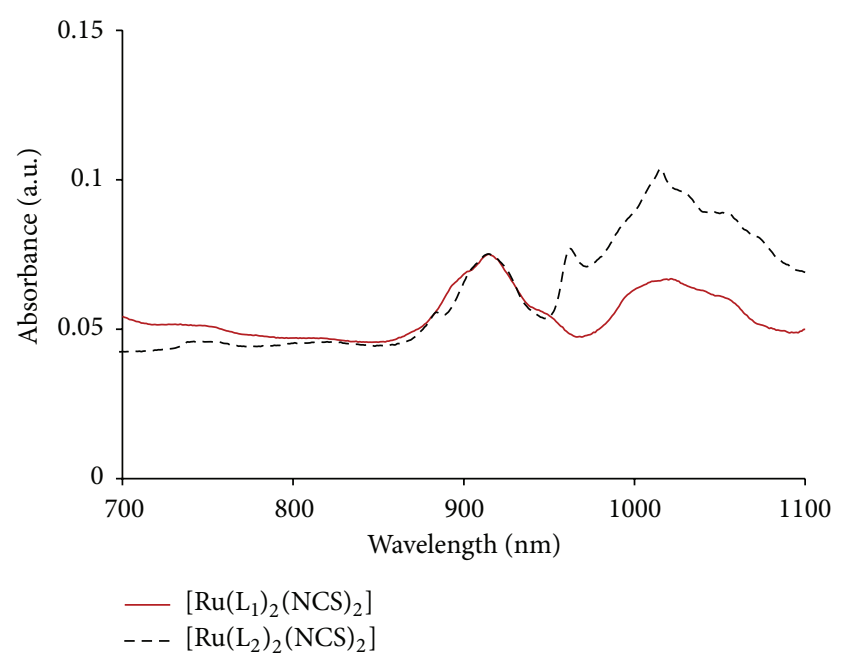

FIGURE 6: Comparison of the lowest energy absorption bands of $\left[\mathrm{Ru}\left(\mathrm{L}_{1}\right)_{2}(\mathrm{NCS})_{2}\right]$ and $\left[\mathrm{Ru}\left(\mathrm{L}_{2}\right)_{2}(\mathrm{NCS})_{2}\right]$ complexes detected in the near infrared region of $900-1022 \mathrm{~nm}(\varepsilon=5.70-7.80 \times$ $\left.10^{3} \mathrm{M}^{-1} \mathrm{~cm}^{-1}\right)$.

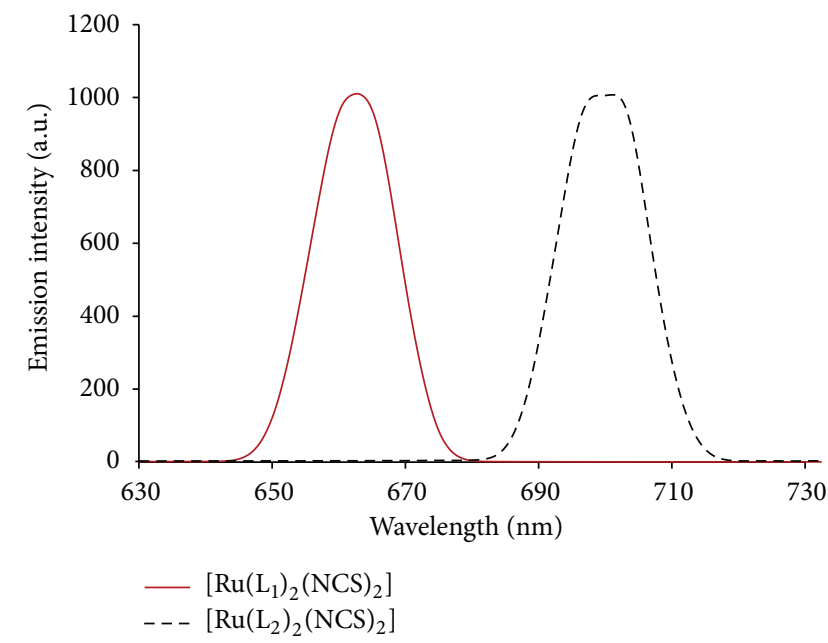

FIgURE 7: Comparison of the emission spectrum of $\left[\mathrm{Ru}\left(\mathrm{L}_{1}\right)_{2}(\mathrm{NCS})_{2}\right]$ (solid line) with $\left[\mathrm{Ru}\left(\mathrm{L}_{2}\right)_{2}(\mathrm{NCS})_{2}\right]$ (dash line) at a concentration of $1 \times 10^{-3} \mathrm{M}^{-1}$ in DMF solution showing effect of extended $\pi$-conjugation using anthracene.

may also be ascribed to the molecular size of the complexes. It has been reported that as the molecular size increases through the extended $\pi$-conjugation, the density of the states will increase, thus providing more effective coupling channels between the ground and photon-allowed states $[50,51]$. It is well known that conjugated functional organic molecules are useful for the study of electron transport at the molecular scale and that the use of fused-ring systems is a powerful and practical approach. The energy of the LC excited states depends on intrinsic properties of the ligands, such as the HOMO-LUMO energy gap and the singlet-triplet splitting. The intense emission is a significant contribution 
$\left[\mathrm{Ru}\left(\mathrm{L}_{1}\right)_{2}(\mathrm{NCS})_{2}\right]$

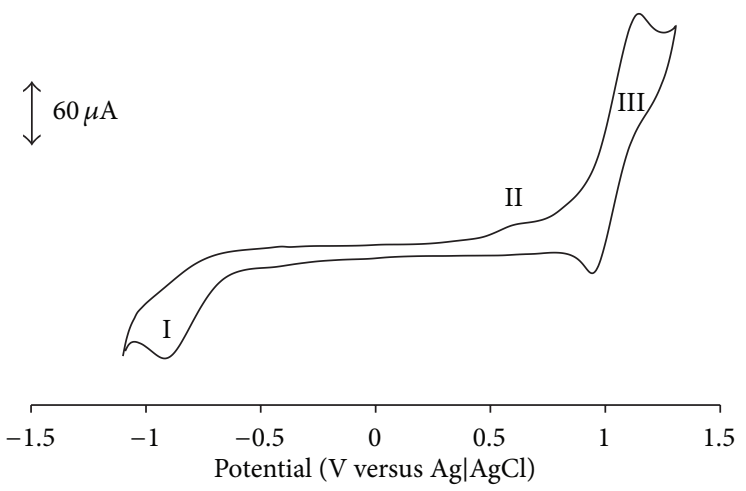

(a)
SQW of $\left[\mathrm{Ru}\left(\mathrm{L}_{1}\right)_{2}(\mathrm{NCS})_{2}\right]$

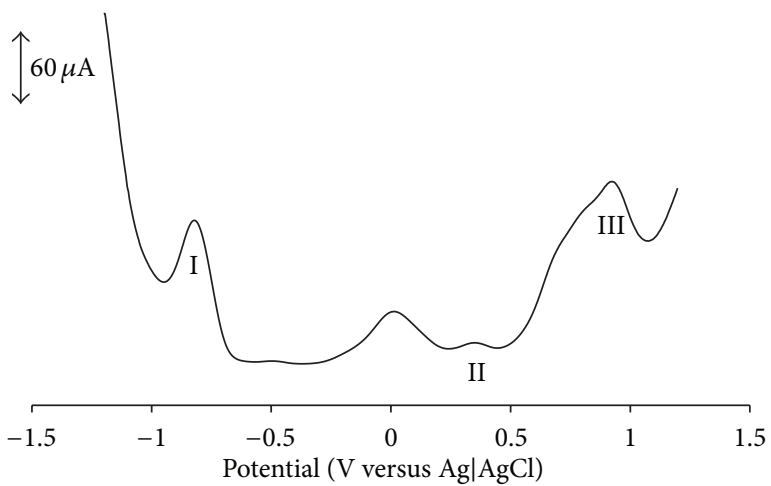

(b)

Figure 8: Cyclic and square wave voltammograms ( $\mathrm{a}$ and $\mathrm{b}$ ) for $\left[\mathrm{Ru}\left(\mathrm{L}_{2}\right)_{2}(\mathrm{NCS})_{2}\right]$ complex at $1 \times 10^{-3} \mathrm{M}$ in freshly distilled DMF containing $0.1 \mathrm{M} \mathrm{TBABF}_{4}$ supporting electrolyte. Step potential is $5 \mathrm{mV}$, amplitude is $60 \mathrm{mV}$ versus $\mathrm{Ag} \mid \mathrm{AgCl}$, and frequency is $10 \mathrm{~Hz}$. Scan rate is $100 \mathrm{~m}$ $\mathrm{Vs}^{-1}$ versus $\mathrm{Ag} \mid \mathrm{AgCl}$.

to the excited state from an interaction between the metal $\mathrm{d}$-orbital and the ligand $\pi$-systems [52].

2.5. Electrochemical Study. The cyclic and square wave voltammograms of the complex $\left[\mathrm{Ru}\left(\mathrm{L}_{1}\right)_{2}(\mathrm{NCS})_{2}\right]$ were examined in the potential range +1.5 to $-1.5 \mathrm{~V}$ and at a scan rate $50 \mathrm{mV} \cdot \mathrm{s}^{-1}$ using $\mathrm{Ag} \mid \mathrm{AgCl}$ electrode in DMF solvent with $0.1 \mathrm{M}$ tetrabutylammonium hexafluorophosphate as supporting electrolyte (Figure 8(a)). The voltammograms display the $\mathrm{Ru}^{2+} / \mathrm{Ru}^{3+}$ couple at positive potential and ligand based on reduction couples at negative potential. A reversible oneelectron oxidation peak at $\mathrm{E}_{1 / 2}=+1.04 \mathrm{~V}$ (process III) was attributed to $\mathrm{Ru}^{2+} / \mathrm{Ru}^{3+}$ wave couple, which was found at a slightly reduced potential $(\sim+0.14 \mathrm{~V})$ in the square wave voltammogram (Figure $8(\mathrm{~b})$ ). The reason for the observed shift in potential could not be adequately accounted for, though, the possibility of instrumental error is not precluded $[40,49]$. In comparison, the highly efficient $\mathrm{Ru}(\mathrm{II})$ DSC sensitizers commonly possess $\mathrm{Ru}^{2+} / \mathrm{Ru}^{3+}$ potentials close to or greater than ca. $+0.9 \mathrm{~V}$ while maintaining a sizeable over potential versus $\mathrm{I}^{-} / \mathrm{I}_{3}{ }^{-}$couple to ensure the fast regeneration of the oxidized sensitizer [53, 54]. To circumvent this limitation, one possible solution is to attach a strong electron-withdrawing group onto the ancillary so that oxidation potentials can be adequately controlled [55]. One identified irreversible oxidation peak process II was observed at $+0.58 \mathrm{~V}$; this was ascribed to the ring oxidation of either the phenanthroline or anthracene and/or a contribution from the carboxylate ions present in the complex. At the negative potential, pseudoirreversible wave was observed at $-0.89 \mathrm{~V}$ for process I. The more positive reduction potential may be assigned to the contribution from the liganddue to an additional $(\mathrm{C}=\mathrm{C})$ conjugative $\pi$-bond as found in the structure of anthracene since the ligand contains the electron withdrawing - $\mathrm{COOH}$ group of the anchoring ligand being responsible for lowering the LUMO levels.

\section{Experimental}

3.1. Materials and General Physical Measurements. All chemical and reagents were analytically pure and used without further purification. 5-Bromo-1,10-phenanthroline and 5-(9-bromoanthracene)-1,10-phenanthroline were synthesized as described in the literature [41]. 5-(9Anthracenyl-10-(trans-2-methyl-2-butenoic acid)-1,10phenanthroline) $\left(\mathrm{L}_{1}\right)$ and 5-(trans-2-methyl-2-butenoic acid)-1,10-phenanthroline $\left(\mathrm{L}_{2}\right)$ were synthesized by the literature procedure [38] with slight modifications (Scheme 1). All thin layer chromatography (TLC) analyses were done with aluminium sheet precoated with normal phase silica gel $60 \mathrm{~F}_{254}$ (Merck, $0.20 \mathrm{~mm}$ thickness) unless otherwise stated. The TLC plates were developed using any of the following solvent systems: solvent system A: dichloromethane-methanol (9:1); solvent system B: dichloromethane-methanol $(7: 3)$; solvent system C: diethyl ether-methanol $(1: 1)$. Gel filtration was performed using Sephadex LH-20 previously swollen in specified solvent (s) prior to loading of extract onto the column $(3.5 \mathrm{~cm} \times$ $8.5 \mathrm{~cm}$ ). Melting points were determined using a Gallenkamp electrothermal melting point apparatus. Microanalyses (C, $\mathrm{H}, \mathrm{N}$, and $\mathrm{S}$ ) were carried out with a Fisons elemental analyzer and infrared spectra were obtained with $\mathrm{KBr}$ discs or nujol on a Perkin Elmer System 2000 FT-IR Spectrophotometer. UV-Vis and fluorescence spectra were recorded in a $1 \mathrm{~cm}$ path length quartz cell on a Perkin Elmer Lambda 35 spectrophotometer and Perkin Elmer Lambda 45 spectrofluorometer, respectively. ${ }^{1} \mathrm{H}$ - and ${ }^{13} \mathrm{C}-\mathrm{NMR}$ spectra were run on a Bruker EMX $400 \mathrm{MHz}$ spectrometer for ${ }^{1} \mathrm{H}$ and $100 \mathrm{MHz}$ for ${ }^{13} \mathrm{C}$. The chemical shift values 
were reported in parts per million (ppm) relative to (TMS) as internal standard. Chemical shifts were reported for the ligands and complex with respect to $\mathrm{CDCl}_{3}$ at $\delta_{\mathrm{c}} 77.00$ and $\delta_{\mathrm{H}}$ $\mathrm{CDCl}_{3}$ at 7.26. Electrochemical experiment was performed using a PGSTAT 302 Autolab potentiostat (EcoChemie, Utrecht, The Netherlands) driven by the general purpose electrochemical system data processing software (GPES, software version 4.9). A conventional three-electrode system was used. The working electrode was a bare glassy carbon electrode (GCE); $\mathrm{Ag} \mid \mathrm{AgCl}$ wire and platinum wire were used as the pseudo-reference and auxiliary electrodes, respectively. The potential response of the $\mathrm{Ag} \mid \mathrm{AgCl}$ pseudoreference electrode was less than the $\mathrm{Ag} \mid \mathrm{AgCl}(3 \mathrm{M} \mathrm{KCl})$ by $0.015 \pm 0.003 \mathrm{~V}$. Prior to use, the electrode surface was polished with alumina on a Buehler felt pad and rinsed with excess Millipore water. All electrochemical experiments were performed in freshly distilled dry DMF containing $\mathrm{TBABF}_{4}$ as supporting electrolyte.

3.2. Synthesis of 5-(9-Anthracenyl-10-(trans-2-Methyl-2butenoic acid)-1,10-phenanthroline) ( $\left.L_{1}\right)$. 5-Bromo-1,10phenanthroline ( $1 \mathrm{~g}, 3.86 \mathrm{mmol})$ and 9-bromo-10-(2-methyl2-butenoic acid)-anthracene $(1.37 \mathrm{~g}, 3.86 \mathrm{mmol})$ were dissolved in benzene-dichloromethane $(70 \mathrm{~mL}, \mathrm{v} / \mathrm{v}, 1: 1)$, followed by the addition of $\mathrm{Et}_{3} \mathrm{~N}(1 \mathrm{~mL}), \mathrm{KOH}(0.27 \mathrm{~g}$, $4.82 \mathrm{mmol})$, and palladium-carbide $(0.05 \mathrm{~g})$. The reaction was carried out under reflux for $12 \mathrm{~h}$ at temperature 110$120^{\circ} \mathrm{C}$. Colour: yellow crystalline solid. Melting point: $167-169^{\circ} \mathrm{C}$; percentage yield: $1.40 \mathrm{~g}, 59 \%$, IR (KBr) $\nu_{\max } / \mathrm{cm}^{-1}$ : 3427, 3055, 2979, 2924, 2552, 1966, 1871, 1802, 1579, 1558, 1453, 1417, 1304, 1255, 1140, 1089, 1040, 994, 926, 756, 654, 619, 579. ${ }^{1} \mathrm{H}-\mathrm{NMR}\left(\mathrm{CDCl}_{3}\right): \delta 9.18(\mathrm{~d}, J=3.2 \mathrm{~Hz}), 8.23(\mathrm{~d}, J=$ $7.2 \mathrm{~Hz}$ ), 7.77 (s), 7.62 (dd, $J=4.4,8.0 \mathrm{~Hz}), 6.97(\mathrm{~d}, J=7.2 \mathrm{~Hz})$, $1.81\left(\mathrm{t}, \mathrm{CH}_{3}\right), 1.23\left(\mathrm{t}, \mathrm{CH}_{3}\right) .{ }^{13} \mathrm{C}-\mathrm{NMR}\left(\mathrm{CDCl}_{3}\right): \delta 150.28$, $146.19,139.25,135.97,128.61,126.49,123.04,14.42$, and 11.74. Elemental analysis: calculated $\mathrm{H} 4.88, \mathrm{C} 81.72$, and $\mathrm{N} 6.16$; required $\mathrm{H}$ 4.71, $\mathrm{C}$ 81.60, and $\mathrm{N}$ 6.31. Molecular formula: $\mathrm{C}_{31} \mathrm{H}_{22} \mathrm{~N}_{2} \mathrm{O}_{2}$.

3.3. Synthesis of 5-(trans-2-Methyl-2-butenoic acid)-1,10phenanthroline $\left(L_{2}\right)$. 5-Bromo-1,10-phenanthroline $(1.0 \mathrm{~g}$, $3.86 \mathrm{mmol})$ and trans-2-methyl-2-butenoic acid (0.39 g, $3.86 \mathrm{mmol})$ were dissolved in $\mathrm{MeOH}(40 \mathrm{~mL})$ in a $250 \mathrm{~mL}$ flask. $\mathrm{Et}_{3} \mathrm{~N}(1.0 \mathrm{~mL})$ and palladium carbide $(0.050 \mathrm{~g})$ were added and the mixture was refluxed for $8 \mathrm{~h}$ at a temperature between 110 and $120^{\circ} \mathrm{C}$. Colour: white-pink crystalline solid; percentage yield: $0.74 \mathrm{~g}, 53 \%$; melting point: ND; IR ( $\mathrm{KBr}$, $\left.\nu_{\max } / \mathrm{cm}^{-1}\right): 3,419,3,032,2,929,1,694,1,652,1,619,1,589,1,561$, $1,506,1,420,1,385,1,343,1,256,1,219,1,140,1,093,1,080,1,037$, $1,015,843,766,734,769,625$, and $530 .{ }^{1} \mathrm{H}-\mathrm{NMR}\left(\mathrm{CDCl}_{3}\right): \delta$ 11.33 (br, OH), 8.98 (t, $J=4.0 \mathrm{~Hz}, 2 \mathrm{H}, \mathrm{H}-2,9), 7.92$ (d, $J=$ $8.0 \mathrm{~Hz}, 2 \mathrm{H}, \mathrm{H}-4,7), 7.45$ (s, 1H, H-6), 7.35 (2d, $J=4.4 \mathrm{~Hz}$, $2 \mathrm{H}, \mathrm{H}-3,8), 1.68\left(\mathrm{~s}, 3 \mathrm{H}, \mathrm{CH}_{3}\right)$, and 1.59 (d, $\mathrm{J}=6.8 \mathrm{~Hz}, 3 \mathrm{H}$, $\left.\mathrm{CH}_{3}\right) .{ }^{13} \mathrm{C}-\mathrm{NMR}\left(\mathrm{CDCl}_{3}\right): \delta 172.83,150.39,150.30,146.30$, $146.21,138.79,136.13,128.81,128.72,126.68,126.59,123.27$, $123.19,14.74$, and 12.14. Elemental analysis: calculated H 5.07, C 73.37, and $\mathrm{N} \mathrm{10.07;} \mathrm{required} \mathrm{H} 4.99, \mathrm{C} 73.64$, and $\mathrm{N} \mathrm{10.23.}$ Molecular formula: $\mathrm{C}_{17} \mathrm{H}_{14} \mathrm{~N}_{2} \mathrm{O}_{2}$.
3.4. Synthesis of cis-Dithiocyanato-bis-5-(9-anthracenyl-10(trans-2-methyl-2-butenoic acid)-1,10-phenanthrolyl) Ruthenium(II) Complex $\left[\mathrm{Ru}\left(\mathrm{L}_{1}\right)_{2}(\mathrm{NCS})_{2}\right]$. In a $250 \mathrm{~mL}$ flask, $\left[\mathrm{RuCl}_{2}(\mathrm{dmso})_{4}\right](0.05 \mathrm{~g}, 0.11 \mathrm{mmol})$ was dissolved in N,Ndimethylformamide/method mixture $(80 \mathrm{~mL}, 1: 5, \mathrm{v} / \mathrm{v})$ followed by the addition of ligand $\mathrm{L}_{1}(0.10 \mathrm{~g}, 1.22 \mathrm{mmol})$. The mixture was refluxed initially at $120^{\circ} \mathrm{C}$ for $12 \mathrm{~h}$ in the dark and excess of $\mathrm{NH}_{4} \mathrm{NCS}(0.17 \mathrm{~g}, 2.20 \mathrm{mmol})$. Colour: darkbrown solid; melting point: $>260^{\circ} \mathrm{C}$; percentage yield: $0.79 \mathrm{~g}$, 25\%. IR (KBr) $v_{\max } / \mathrm{cm}^{-1}: 3,551,3,479,3,414,3,237,2,928$, 2,104, 1,971, 1,638, 1,617, 1,459, 1,448, 1,304, 1,265, 1,156, 1,090, $1,026,926,804,747,730,622,579,475$, and 404. UV-Vis $\left(\lambda_{\max } / \mathrm{nm}, \varepsilon=\times 10^{4} \mathrm{M}^{-1} \mathrm{~cm}^{-1}, \mathrm{DMF}\right): 348$ (11.70), 365 (17.27), 383 (23.62), 405 (21.23), 437 (5.07), and 522 (6.59). Emission wavelength: $\left(\lambda_{\text {exc. }}=500 \mathrm{~nm}, \lambda_{\text {em }}=660 \mathrm{~nm}\right)$. Selected ${ }^{1} \mathrm{H}$ NMR data $\left(\mathrm{CDCl}_{3}\right): \delta 8.59(\mathrm{dd}, J=4.8,7.2 \mathrm{~Hz}), 7.63(\mathrm{dd}, J$ $=2.8,6.8 \mathrm{~Hz}), 2.95\left(\mathrm{~s}, \mathrm{CH}_{3}\right), 2.88\left(\mathrm{~s}, \mathrm{CH}_{3}\right), 2.17\left(\mathrm{~s}, \mathrm{CH}_{3}\right)$, and $2.04\left(\mathrm{~s}, \mathrm{CH}_{3}\right) .{ }^{13} \mathrm{C}-\mathrm{NMR}\left(\mathrm{CDCl}_{3}\right)$ : ND. Cyclic voltammetry data: $\mathrm{Ru}^{2+} / \mathrm{Ru}^{3+}=+1.04 \mathrm{~V} ; \mathrm{E}_{\text {anodic }}=+0.58 \mathrm{~V} ; \mathrm{E}_{\text {cathodic }}=$ -0.89 V. Elemental analysis: calculated $\mathrm{H} 3.94, \mathrm{C} 68.25, \mathrm{~N}$ 7.44, and S 5.69; required $\mathrm{H}$ 4.22., C 68.55, N 7.76, and S 5.91. Molecular formula: $\mathrm{RuC}_{64} \mathrm{H}_{44} \mathrm{~N}_{6} \mathrm{O}_{4} \mathrm{~S}_{2}$.

3.5. Synthesis of cis-Dithiocyanato-bis-5-(trans-2-methyl-2butenoic acid)-1,10-phenanthrolyl Ruthenium(II) Complex $\left[\mathrm{Ru}\left(\mathrm{L}_{2}\right)_{2}(\mathrm{NCS})_{2}\right]$. In a $250 \mathrm{~mL}$ flask, $\left[\mathrm{RuCl}_{2}(\mathrm{dmso})_{4}\right](0.44 \mathrm{~g}$, $0.90 \mathrm{mmol}$ ) was dissolved in $\mathrm{N}, \mathrm{N}$-dimethylformamide $(40 \mathrm{~mL})$ followed by the addition of ligand $\mathrm{L}_{2}(0.50 \mathrm{~g}$, $1.79 \mathrm{mmol})$. The mixture was refluxed initially at $120^{\circ} \mathrm{C}$ for $2 \mathrm{~h}$ in the dark and excess of $\mathrm{NH}_{4} \mathrm{NCS}(0.27 \mathrm{~g}, 3.59 \mathrm{~mol})$ was added and the same procedure as described above was followed. Colour: orange solid; melting point: $201-204^{\circ} \mathrm{C}$; percentage yield: $0.38 \mathrm{~g}, 38 \%$. IR (KBr) $v_{\max } / \mathrm{cm}^{-1}: 3,423$, 3,058, 2,926, 2,856, 2,086, 2,058, 1,978, 1,631, 1,427, 1,384, $1,221,1,205,1,147,1,056,879,844,773,721,621$, and 559 . UV-Vis $\left(\lambda_{\max } / \mathrm{nm}, \varepsilon=\times 10^{4} \mathrm{M}^{-1} \mathrm{~cm}^{-1}, \mathrm{DMF}\right): 416$ (4.49), 446 (4.82). Emission wavelength: $\left(\lambda_{\text {exc. }}=500 \mathrm{~nm}, \lambda_{\mathrm{em}}=\right.$ $700 \mathrm{~nm}) .{ }^{1} \mathrm{H}-\mathrm{NMR}\left(\mathrm{CDCl}_{3}\right): \delta 8.77(\mathrm{~d}, J=8.0 \mathrm{~Hz}, 4 \mathrm{H}), 8.38$ $(\mathrm{s}, 2 \mathrm{H}), 8.08(\mathrm{~d}, J=4.8 \mathrm{~Hz}, 4 \mathrm{H}), 7.76(\mathrm{dd}, J=5.2,8.0 \mathrm{~Hz}, 4 \mathrm{H})$, and $3.40(\mathrm{~s}, 6 \mathrm{H})$. Selected aromatic ${ }^{13} \mathrm{C}-\mathrm{NMR}$ data $\left(\mathrm{CDCl}_{3}\right)$ : 153.62, 148.13, 137.69, 131.33, 128.92, and 127.17. Elemental analysis: calculated $\mathrm{H} 3.65, \mathrm{C} 55.88, \mathrm{~N} 10.86$, and S 8.29; required $\mathrm{H}$ 3.32, $\mathrm{C} 55.95, \mathrm{~N} 10.51$, and $\mathrm{S}$ 8.59. Molecular formula: $\mathrm{RuC}_{36} \mathrm{H}_{28} \mathrm{~N}_{6} \mathrm{O}_{4} \mathrm{~S}_{2}$.

\section{Conclusions}

With the growing research in the different sections of DSSC, including sensitizers, we have designed, synthesized, and characterized a new ligand, 5-(9-anthracenyl-10-(2-methyl2-butenoic acid)-1,10-phenanthroline $\left(\mathrm{L}_{1}\right)$, and its ruthenium(II) complex $\left[\mathrm{Ru}\left(\mathrm{L}_{1}\right)_{2}(\mathrm{NCS})_{2}\right]$ using FT-IR, ${ }^{1} \mathrm{H} \mathrm{NMR}$, and elemental analysis. The photophysical properties of the complex when compared with previously reported analogue $\left[\mathrm{Ru}\left(\mathrm{L}_{2}\right)_{2}(\mathrm{NCS})_{2}\right]$ complex containing no anthracenyl functionality were found to show higher molar extinction coefficient and shifting of the wavelength maximum to the red as these were attributed to the extension of $\pi$-bond conjugation 
in the molecule. In terms of emission characteristic, however, the wavelength of the complex $\left[\mathrm{Ru}\left(\mathrm{L}_{1}\right)_{2}(\mathrm{NCS})_{2}\right]$ was blueshifted due to the size/molecular weight as more conjugated bonds are introduced.

By comparison of the electroredox property of the complex $\left[\mathrm{Ru}\left(\mathrm{L}_{1}\right)_{2}(\mathrm{NCS})_{2}\right]$ to other reported $\mathrm{Ru}(\mathrm{II})$ polypyridyl complexes used as photosensitizers for dye-sensitized solar cells (DSSCs) applications, the complex showed a good electroredox property. The $\mathrm{Ru}^{2+} / \mathrm{Ru}^{3+}$ oxidation potential $\left(\mathrm{E}_{\text {ox }}{ }^{\circ}\right)$ is measured as $1.04 \mathrm{~V}$ (versus $\mathrm{AgCl}$ ), which is larger than that of the $\mathrm{I}^{-} / \mathrm{I}_{3}{ }^{-}$redox potential $(\sim 0.35 \mathrm{~V}$ versus NHE). It has been revealed that oxidation potentials provide firsthand information on whether newly developed dyes can be efficiently regenerated by the $\mathrm{I}^{-} / \mathrm{I}_{3}{ }^{-}$redox couple [5658]. Particularly, for this molecule, further work is ongoing in our laboratory to establish the solar-to-electrical energy conversion efficiency $(\eta)$ in the dye-sensitized solar cells (DSSCs). However, due to $\pi$-electron cloud overlaps in anthracene derivatives, the molecule could be useful in other applications, including organic electroluminescence material for biosensitizers and display devices such as organic light emitting diode (OLED), organic thin film transistor (OTFT), wearable display, photochromic agents, and electronic paper.

\section{Conflict of Interests}

The authors declare that there is no conflict of interests regarding the publication of this paper.

\section{Acknowledgments}

Financial support from the South African National Energy Research Institute (SANERI) and Govan Mbeki Research Centre, University of Fort Hare, Alice, South Africa, is highly appreciated.

\section{References}

[1] M. A. Fox and M. Chanon, Photoinduced Electron Transfer, Elsevier, Amsterdam, The Netherlands, 1988.

[2] M. Gratzel, Heterogeneous Photochemical Electron Transfer, CRC Press, Boca Raton, Fla, USA, 1989.

[3] O. U. Yoping, G. Chen, J. Yin, G.-A. O. Yu, and S. H. Liu, "2Rotaxane based on terpyridyl bimetal ruthenium complexes and $\beta$-cyclodextrin as organic sensitizer for dye-sensitized solar cells," Journal of Coordination Chemistry, vol. 64, no. 17, pp. 3062-3067, 2011.

[4] B. C. O'Regan and J. R. Durrant, "Kinetic and energetic paradigms for dye-sensitized solar cells: moving from the ideal to the real," Accounts of Chemical Research, vol. 42, no. 11, pp. 1799-1808, 2009.

[5] H. J. Snaith, "Estimating the maximum attainable efficiency in dye-sensitized solar cells," Advanced Functional Materials, vol. 20, no. 1, pp. 13-19, 2010.

[6] A. Harriman, M. Hissler, A. Khatyr, and R. Ziessel, "The photophysical properties of hybrid metal complexes containing both $2,2^{\prime}$-bipyridine and $2,2^{\prime}: 6^{\prime}, 2^{\prime}$-terpyridine units," European Journal of Inorganic Chemistry, no. 5, pp. 955-959, 2003.
[7] V. Duprez, M. Biancardo, H. Spanggaard, and F. C. Krebs, "Synthesis of conjugated polymers containing terpyridine-ruthenium complexes: photovoltaic applications," Macromolecules, vol. 38, no. 25, pp. 10436-10448, 2005.

[8] C. W. Hsu, S. T. Ho, K. L. Wu, Y. Chi, S. H. Liu, and P. T. Chou, "Ru(II) sensitizers with a tridentate heterocyclic cyclometalate for dye-sensitized solar cells," Energy \& Environmental Science, vol. 5, no. 6, pp. 7549-7554, 2012.

[9] L. M. Goncalves, V. de zea Bermudez, H. A. Ribeiro, and A. M. Mendes, "Dye-sensitized solar cells: a safe bet for the future," Energy \& Environmental Science, vol. 1, no. 6, pp. 655-667, 2008.

[10] J.-H. Yum, P. Chen, M. Grätzel, and M. K. Nazeeruddin, "Recent developments in solid-state dye-sensitized solar cells," ChemSusChem, vol. 1, no. 8-9, pp. 699-707, 2008.

[11] T. W. Hamann, R. A. Jensen, A. B. F. Martinson, H. van Ryswyk, and J. T. Hupp, "Advancing beyond current generation dyesensitized solar cells," Energy \& Environmental Science, vol. 1, no. 1, pp. 66-78, 2008.

[12] M. Gratzel, "Recent advances in sensitized mesoscopic solar cells," Accounts of Chemical Research, vol. 42, no. 11, pp. 17881798, 2009.

[13] Y. Luo, D. Li, and Q. Meng, "Towards optimization of materials for dye-sensitized solar cells," Advanced Materials, vol. 21, no. 45, pp. 4647-4651, 2009.

[14] A. Hagfeldt, G. Boschloo, L. Sun, L. Kloo, and H. Pettersson, "Dye-sensitized solar cells," Chemical Reviews, vol. 110, no. 11, pp. 6595-6663, 2010.

[15] Z. Ning, Y. Fu, and H. Tian, "Improvement of dye-sensitized solar cells: what we know and what we need to know," Energy \& Environmental Science, vol. 3, no. 9, pp. 1170-1181, 2010.

[16] J. Desilvestro, M. Gratzel, L. Kavon, J. Moser, and J. Augustynski, "Highly efficient sensitization of titanium dioxide," Journal of the American Chemical Society, vol. 107, no. 10, pp. 2988-2990, 1985.

[17] N. Vlachopoulos, P. Liska, J. Augustynski, and M. Grätzel, "Very efficient visible light energy harvesting and conversion by spectral sensitization of high surface area polycrystalline titanium dioxide films," Journal of the American Chemical Society, vol. 110, no. 4, pp. 1216-1220, 1988.

[18] P. Liska, N. Vlachopoulos, M. K. Nazeeruddin, P. Comte, and M. Gratzel, "cis-diaquabis $\left(2,2^{\prime}\right.$-bipyridyl- 4,4 ' dicarboxylate)ruthenium(II) sensitizes wide band gap oxide semiconductors very efficiently over a broad spectral range in the visible," Journal of the American Chemical Society, vol. 110, no. 11, pp. 3686-3687, 1988.

[19] M. Chandrasekharam, G. Rajkumar, C. S. Rao, P. Y. Reddy, and M. L. Kantam, "Change of dye bath for sensitisation of nanocrystalline $\mathrm{TiO}_{2}$ films: enhances performance of dyesensitized solar cells," Advances in OptoElectronics, vol. 2011, Article ID 376369, 9 pages, 2011.

[20] M. Chandrasekharam, G. Rajkumar, C. S. Rao, T. Suresh, and P. Y. Reddy, "Phenothiazine conjugated bipyridine as ancillary ligand in $\mathrm{Ru}(\mathrm{II})$-complexes for application in dye sensitized solar cell," Synthetic Metals, vol. 161, no. 15-16, pp. 1469-1476, 2011.

[21] B.-S. Chen, K. Chen, Y.-H. Hong et al., "Neutral, panchromatic $\mathrm{Ru}(\mathrm{ii})$ terpyridine sensitizers bearing pyridine pyrazolate chelates with superior DSSC performance," Chemical Communications, no. 39, pp. 5844-5846, 2009.

[22] Y. H. Jang, X. Xin, M. Byun, Y. J. Jang, Z. Lin, and D. H. Kim, "An unconventional route to high-efficiency dye-sensitized solar 
cells via embedding graphitic thin films into $\mathrm{TiO}_{2}$ nanoparticle photoanode," Nano Letters, vol. 12, no. 1, pp. 479-485, 2012.

[23] T. A. Heimer, C. A. Bignozzi, and G. J. Meyer, "Molecular level photovoltaics: the electrooptical properties of metal cyanide complexes anchored to titanium dioxide," The Journal of Physical Chemistry, vol. 97, no. 46, pp. 11987-11994, 1993.

[24] R. Argazzi, C. A. Bignozzi, T. A. Heimer, F. N. Castellano, and G. J. Meyer, "Enhanced spectral sensitivity from ruthenium(II) polypyridyl based photovoltaic devices," Inorganic Chemistry, vol. 33, no. 25, pp. 5741-5749, 1994.

[25] V. Balzani and F. Scandola, Supramolecular Photochemistry, Ellis Horwood, Chichester, UK, 1991.

[26] M. Duati, S. Fanni, and J. G. Vos, "A new luminescent Ru(terpy) complex incorporating a 1,2,4-triazole based $\sigma$-donor ligand," Inorganic Chemistry Communications, vol. 3, no. 2, pp. 68-70, 2000.

[27] A. Juris, S. Campagna, V. Balzani, G. Gremaud, and A. von Zelewsky, "Absorption spectra, luminescence properties, and electrochemical behavior of tris-heteroleptic ruthenium(II) polypyridine complexes," Inorganic Chemistry, vol. 27, no. 20, pp. 3652-3655, 1988.

[28] A. Prasanna de Silva, D. B. Fox, T. S. Moody, and S. M. Weir, "Luminescent sensors and photonic switches," Pure and Applied Chemistry, vol. 73, no. 3, pp. 503-511, 2001.

[29] J. R. Winkler, D. G. Nocera, K. M. Yocom, E. Bordignon, and H. B. Gray, "Electron-transfer kinetics of pentaammineruthenium(III)(histidine-33)-ferricytochrome c. Measurement of the rate of intramolecular electron transfer between redox centers separated by $15 \AA$ in a protein," Journal of the American Chemical Society, vol. 104, no. 21, pp. 5798-5800, 1982.

[30] H. Sugihara, L. P. Singh, K. Sayama, H. Arakawa, M. K. Nazeeruddin, and M. Gratzel, "Efficient photosensitization of nanocrystalline $\mathrm{TiO}_{2}$ films by a new class of sensitizer: cis-dithiocyanato bis(4,7-dicarboxy-1,10phenanthroline)ruthenium(II)," Chemistry Letters, vol. 27, no. 10, pp. 1005-1006, 1998.

[31] T. Renouard, R.-A. Fallahpour, M. K. Nazeeruddin et al., "Novel ruthenium sensitizers containing functionalized hybrid tetradentate ligands: synthesis, characterization, and INDO/S analysis," Inorganic Chemistry, vol. 41, no. 2, pp. 367-378, 2002.

[32] P. Wang, S. M. Zakeeruddin, J. E. Moser et al., "Stable new sensitizer with improved light harvesting for nanocrystalline dye-sensitized solar cells," Advanced Materials, vol. 16, no. 20, pp. 1806-1811, 2004.

[33] P. Wang, C. Klein, R. Humphry-Baker, S. M. Zakeeruddin, and M. Gratzel, "A high molar extinction coefficient sensitizer for stable dye-sensitized solar cells," Journal of the American Chemical Society, vol. 127, no. 3, pp. 808-809, 2005.

[34] C. Y. Chen, S. J. Wu, J. Y. Li, C. G. Wu, J. G. Chen, and K. C. Ho, "A new route to enhance the light-harvesting capability of ruthenium complexes for dye-sensitized solar cells," Advanced Materials, vol. 19, no. 22, pp. 3888-3891, 2007.

[35] C. Klein, M. K. Nazeeruddin, P. Liska et al., "Engineering of a novel ruthenium sensitizer and its application in dye-sensitized solar cells for conversion of sunlight into electricity," Inorganic Chemistry, vol. 44, no. 2, pp. 178-180, 2005.

[36] C.-Y. Chen, S.-J. Wu, C.-G. Wu, J.-G. Chen, and K.-C. Ho, "A ruthenium complex with superhigh light-harvesting capacity for dye-sensitized solar cells," Angewandte ChemieInternational Edition, vol. 45, no. 35, pp. 5822-5825, 2006.
[37] A. O. Adeloye, "Synthesis, photophysical and electrochemical properties of a mixed bipyridyl-phenanthrolyl ligand $\mathrm{Ru}(\mathrm{II})$ heteroleptic complex having trans-2-methyl-2-butenoic acid functionalities," Molecules, vol. 16, no. 10, pp. 8353-8367, 2011.

[38] A. O. Adeloye and P. A. Ajibade, "Synthesis and characterization of a heteroleptic $\mathrm{Ru}$ (II) complex of phenanthroline containing Oligo-anthracenyl carboxylic acid moieties," International Journal of Molecular Sciences, vol. 11, no. 9, pp. 3158-3176, 2010.

[39] A. O. Adeloye and P. A. Ajibade, "Synthesis and characterization of a $\mathrm{Ru}(\mathrm{II})$ complex with functionalized phenanthroline ligands having single-double linked anthracenyl and 1-methoxy-1buten-3-yne moieties,' Molecules, vol. 15, no. 11, pp. 7570-7581, 2010.

[40] A. O. Adeloye and P. A. Ajibade, "A high molar extinction coefficient mono-anthracenyl bipyridyl heteroleptic ruthenium(II) complex: synthesis, photophysical and electrochemical properties," Molecules, vol. 16, no. 6, pp. 4615-4631, 2011.

[41] P. V. Vyas, A. K. Bhatt, G. Ramachandraiah, and A. V. Bedekar, "Environmentally benign chlorination and bromination of aromatic amines, hydrocarbons and naphthols," Tetrahedron Letters, vol. 44, no. 21, pp. 4085-4088, 2003.

[42] I. P. Evans, A. Spencer, and G. Wilkinson, "Dichlorotetrakis(dimethyl sulphoxide)ruthenium(II) and its use as a source material for some new ruthenium(II) complexes," Journal of the Chemical Society, Dalton Transactions, no. 2, pp. 204209, 1973.

[43] C. A. Mitsopoulou, I. Veroni, A. I. Philippopoulos, and P. Falaras, "Synthesis, characterization and sensitization properties of two novel mono and bis carboxyl-dipyrido-phenazine ruthenium(II) charge transfer complexes," Journal of Photochemistry and Photobiology A: Chemistry, vol. 191, no. 1, pp. 6-12, 2007.

[44] J. L. Burmeister, "Recent developments in the coordination chemistry of ambidentate ligands," Coordination Chemistry Reviews, vol. 1, no. 1-2, pp. 205-221, 1966.

[45] R. M. Silverstein, G. C. Bassler, and T. C. Morrill, Spectrometric Identification of Organic Compounds, John Wiley \& Sons, New York, NY, USA, 5th edition, 1991.

[46] Y. Sun, A. C. Onicha, M. Myahkostupov, and F. N. Castellano, "Viable alternative to N719 for dye-sensitized solar cells," Applied Materials and Interfaces, vol. 2, no. 7, pp. 2039-2045, 2010.

[47] M. Guo, P. Diao, Y.-J. Ren, F. Meng, H. Tian, and S.-M. Cai, "Photoelectrochemical studies of nanocrystalline $\mathrm{TiO}_{2}$ cosensitized by novel cyanine dyes," Solar Energy Materials and Solar Cells, vol. 88, no. 1, pp. 23-35, 2005.

[48] A. Juris, V. Balzani, F. Barigelletti, S. Campagna, P. Belser, and $\mathrm{A}$. von Zelewsky, "Ru(II) polypyridine complexes: photophysics, photochemistry, eletrochemistry, and chemiluminescence," Coordination Chemistry Reviews, vol. 84, pp. 85-277, 1988.

[49] A. O. Adeloye, T. O. Olomola, A. I. Adebayo, and P. A. Ajibade, "A high molar extinction coefficient bisterpyridyl homoleptic $\mathrm{Ru}(\mathrm{II})$ complex with trans-2- ethyl-2-butenoic acid functionality: potential dye for dye-sensitized solar cells," International Journal of Molecular Sciences, vol. 13, no. 3, pp. 3511-3526, 2012.

[50] S. K. Lee, W. J. Yang, J. J. Choi, C. H. Kim, S.-J. Jeon, and B. R. Cho, "2,6-bis[4-(p-dihexylaminostyryl)-styryl]anthracene derivatives with large two-photon cross sections," Organic Letters, vol. 7, no. 2, pp. 323-326, 2005.

[51] A. P. Halverson, T. A. Elmaaty, and L. W. Castle, "Complexes of (bpy) $2 \mathrm{Ru}(\mathrm{II})$ and (Ph2bpy)2Ru(II) with a series of 
thienophenanthroline ligands: synthesis, characterization, and electronic spectra," Journal of Coordination Chemistry, vol. 64, no. 21, pp. 3693-3699, 2011.

[52] D. M. Roundhill, Photochemistry and Photophysics of Metal Complexes, Plenum Press, New York, NY, USA, 1993.

[53] T. J. Meyer and M. H. V. Huynh, "The remarkable reactivity of high oxidation state ruthenium and osmium polypyridyl complexes," Inorganic Chemistry, vol. 42, no. 25, pp. 8140-8160, 2003.

[54] G. Boschloo and A. Hagfeldt, "Characteristics of the iodide/triiodide redox mediator in dye-sensitized solar cells," Accounts of Chemical Research, vol. 42, no. 11, pp. 1819-1826, 2009.

[55] P. G. Bomben, T. J. Gordon, E. Schott, and C. P. Berlinguette, "A trisheteroleptic cyclometalated RuII sensitizer that enables high power output in a dye-sensitized solar cell," Angewandte Chemie - International Edition, vol. 50, no. 45, pp. 10682-10685, 2011.

[56] D. Kuang, C. Klein, S. Ito et al., "High-efficiency and stable mesoscopic dye-sensitized solar cells based on a high molar extinction coefficient ruthenium sensitizer and nonvolatile electrolyte," Advanced Materials, vol. 19, no. 8, pp. 1133-1137, 2007.

[57] P. Wang, S. M. Zakeeruddin, J. E. Moser, M. K. Nazeeruddin, T. Sekiguchi, and M. Grätzel, "A stable quasi-solid-state dyesensitized solar cell with an amphiphilic ruthenium sensitizer and polymer gel electrolyte," Nature Materials, vol. 2, no. 6, pp. 402-407, 2003.

[58] M. Chandrasekharam, G. Rajkumar, C. S. Rao, T. Suresh, Y. Soujanya, and P. Y. Reddy, "High molar extinction coefficient $\mathrm{Ru}(\mathrm{II})$-mixed ligand polypyridyl complexes for dye sensitized solar cell application," Advances in OptoElectronics, vol. 2011, Article ID 432803, 11 pages, 2011. 

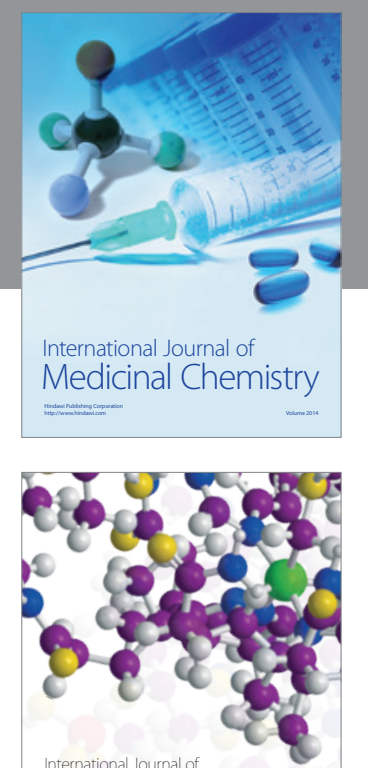

\section{Carbohydrate} Chemistry

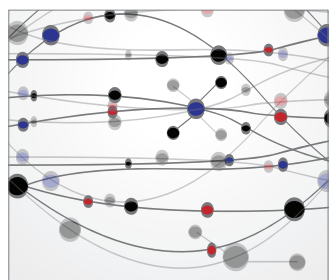

The Scientific World Journal
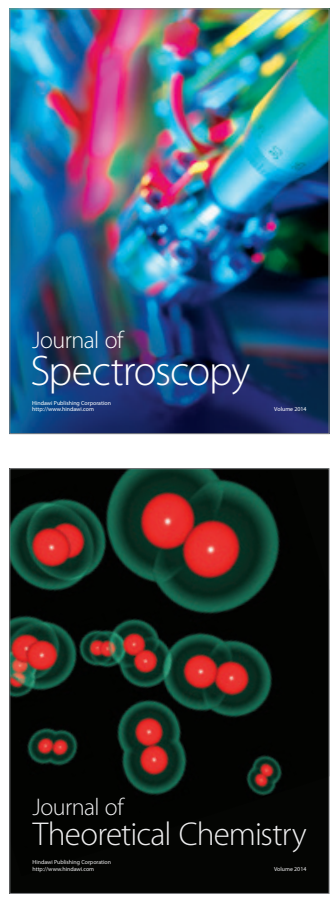
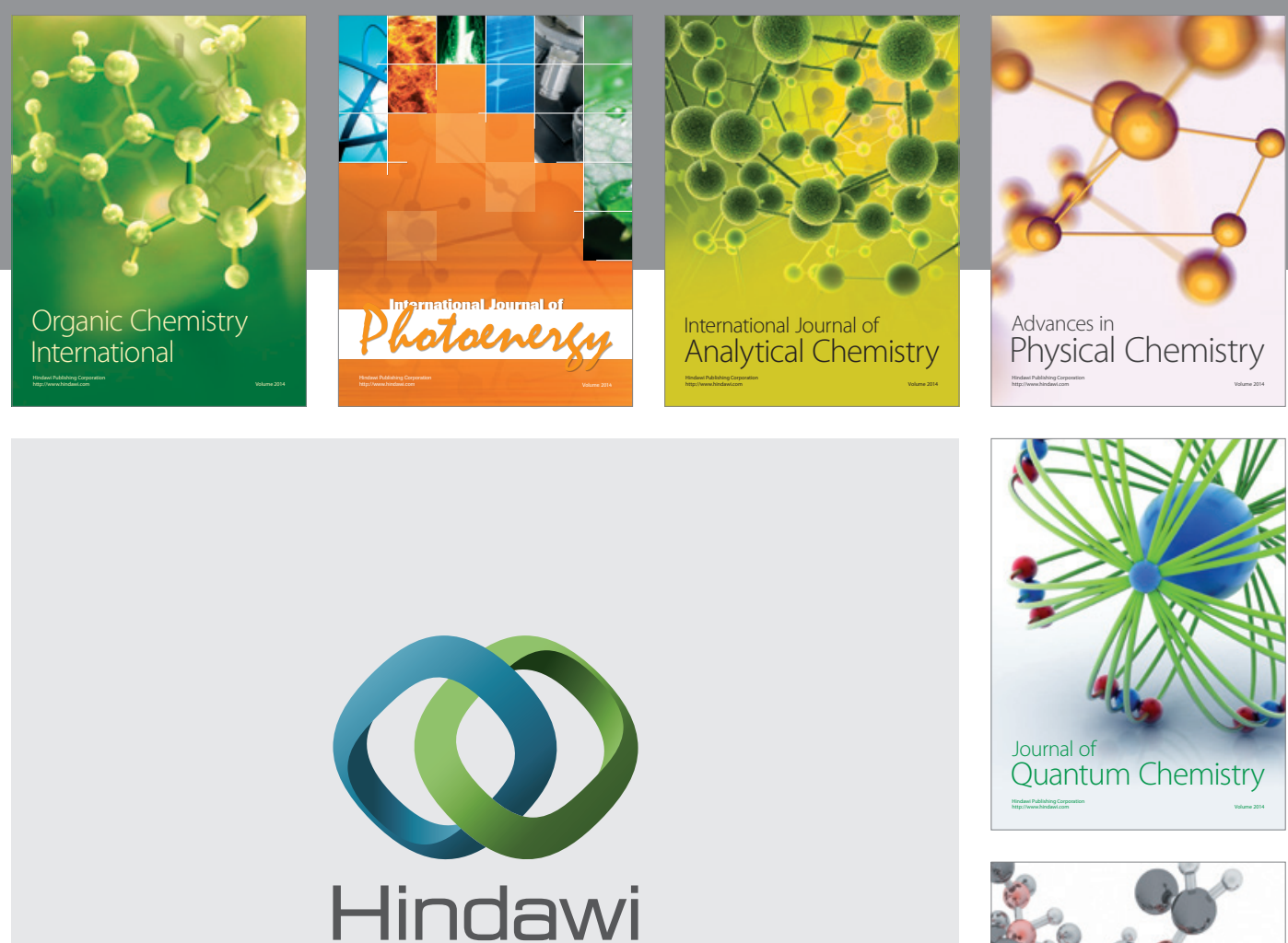

Submit your manuscripts at

http://www.hindawi.com

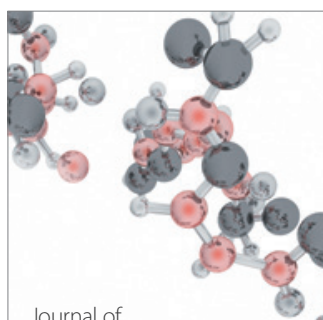

Analytical Methods

in Chemistry

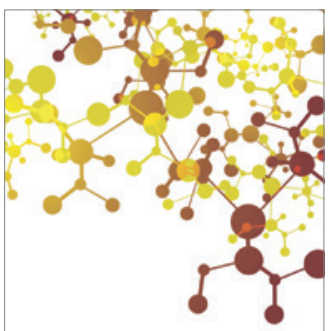

Journal of

Applied Chemistry

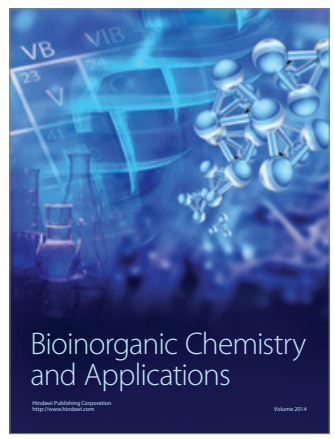

Inorganic Chemistry
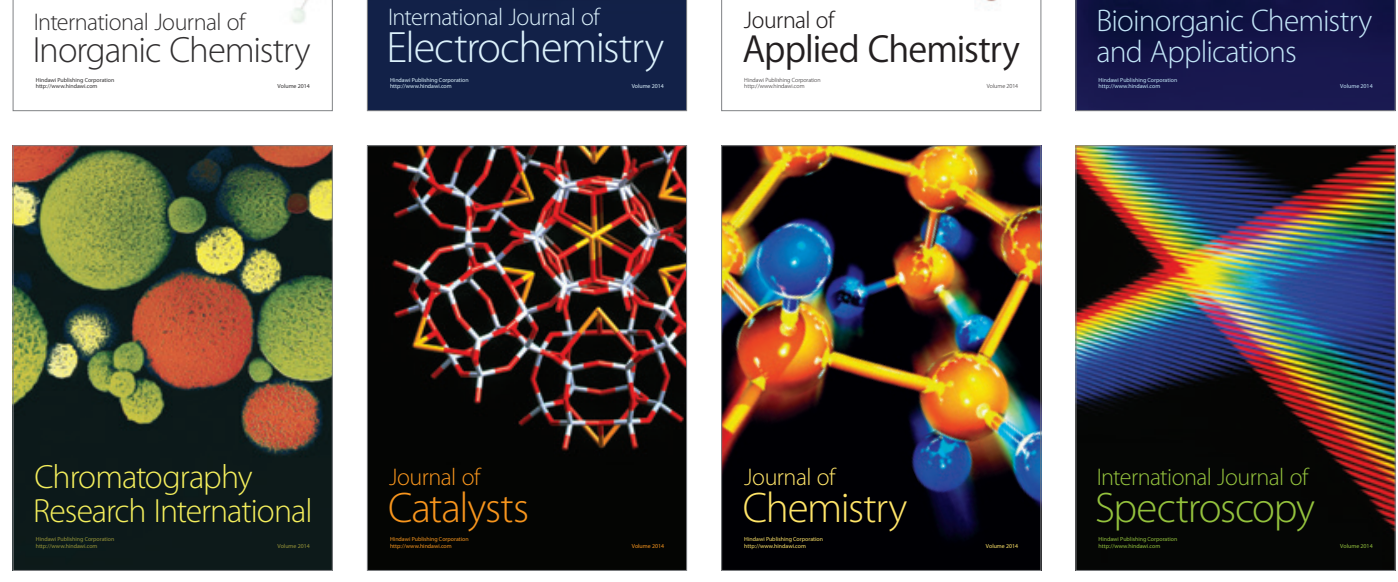